\title{
Antagonistic effects of selenium on cadmium-induced apoptosis by restoring the mitochondrial dynamic equilibrium and energy metabolism in chicken spleens
}

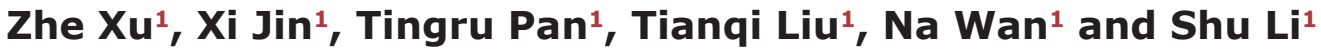 \\ ${ }^{1}$ College of Veterinary Medicine, Northeast Agricultural University, Harbin, 150030, P. R. China
}

Correspondence to: Shu Li, email: lishu@neau.edu.cn

Keywords: cadmium, selenium, spleens, mitochondrial dynamics, apoptosis

Received: January 28, $2017 \quad$ Accepted: April 12, $2017 \quad$ Published: April 30, 2017

Copyright: Xu et al. This is an open-access article distributed under the terms of the Creative Commons Attribution License 3.0 (CC BY 3.0 ), which permits unrestricted use, distribution, and reproduction in any medium, provided the original author and source are credited.

\section{ABSTRACT}

The aim of this study was to investigate the mechanism of cadmium-induced apoptosis in chicken spleens and the antagonistic effects of selenium. We duplicated the selenium-cadmium interaction model and examined the expression of apoptosis-, immune-, mitochondrial dynamics- and energy metabolism-related genes. The results demonstrated that after treatment with cadmium, the frequency of apoptosis was significantly increased, and the morphological characteristics of apoptosis were observed. The expression of pro-apoptotic genes was increased, and that of antiapoptotic genes was decreased. The mRNA levels of tumor necrosis factor-a and interlenkin-1 $\beta$ were observably increased, but the interlenkin- 2 and interferon- $y$ levels were markedly decreased. Furthermore, the mRNA and protein levels of dynaminrelated protein 1 and mitochondrial fission factor were significantly enhanced, whereas mitofusin 1, mitofusin 2, and optic atrophy 1 were markedly decreased. The expression of hexokinase 1 , hexokinase 2 , aconitase 2, lactate dehydrogenase $A$, lactate dehydrogenase $B$, succinatedehydrogenase $B$, pyruvate kinase and phosphofructokinase were also reduced. Selenium supplements remarkably attenuated cadmium-induced effects $(p<0.05)$. Based on the above results, conclude that the cadmium treatment promoted a mitochondrial dynamic imbalance and reduced energy metabolism, leading to apoptosis and immune dysfunction in chicken spleens, and selenium had an antagonistic effect on Cd-induced apoptosis.

\section{INTRODUCTION}

Cadmium $(\mathrm{Cd})$ is a widespread heavy metal pollutant, which can be discharged into the environment during industrial production, including the production of batteries, metal plating, pigments and plastics [1]. Heavy metals may be ingested by animals via respiration or gastrointestinal absorption, resulting in the possible risk of harm to humans through the food web $[2,3]$. Cd accumulates in various tissues and cells and produces toxic effects, such as immune dysfunction and apoptosis. In caprine spleens, the combination of $\mathrm{Cd}$ and molybdenum induced noteworthy damage by promoting cell apoptosis [4]. In the immune organs of chicken, arsenic trioxide exposure increased the levels of heat shock protein, disrupting immune function [5]. Cd was found to induce oxidative stress, endoplasmic reticulum stress, and NO overproduction, which are factors that are believed to be involved in apoptosis [6, 7]. Several studies have reported that $\mathrm{Cd}$ induces apoptosis through a mitochondria-dependent pathway. In rat proximal tubular cells, $\mathrm{Cd}$ induced apoptosis by the breakdown of mitochondrial $\Delta \Psi$ and overproduction of reactive oxygen species (ROS) $[8,9]$. The breakdown of mitochondrial $\Delta \Psi$ and the increased mitochondrial membrane permeability resulted in the release of cytochrome $\mathrm{c}(\mathrm{Cyt}-\mathrm{c})$ from the mitochondria into the cytosol [10]. Furthermore, $\mathrm{Cd}$ increased expression of pro-apoptosis genes (such as Bax and Bak) and decreased expression of anti-apoptosis genes (such as Bcl-2), which may induce the release of Cyt-c [11]. In pancreatic $\beta$-cells, $\mathrm{Cd}$ increased the expression of p53, leading to the release of Cyt-c and apoptosis [12]. Cyt-c activated the caspase protein family (such as caspase 3 and caspase 9) and led to apoptosis [13]. Recent studies have suggested that $\mathrm{Cd}$ induces mitochondrial 
fragmentation by increasing dynamin-related protein 1 (Drp1) expression $[14,15]$. Manganese (Mn) also induced deregulation of expression levels of mitochondria-shaping proteins and exacerbated fragmentation [16]. Mitochondrial fragmentation, in turn, facilitated apoptosis [17]. The Drp1 and mitochondrial fission factor (Mff) mediated mitochondrial membrane fission. Conversely, mitofusin 1 (Mfn1), mitofusin 2 (Mfn2) and optic atrophy 1 (Opa1) mediated mitochondrial membrane fusion. Additionally, several reports revealed that heavy metal toxicity led to energy metabolism dysfunction, resulting in apoptosis. In skeletal muscles of mice, $\mathrm{Cd}$ inhibited the expression of hexokinase (HK) and phosphofructokinase (PFK), disrupting glycolysis and decreasing ATP generation [18]. The reduced glucose metabolism and energy production impaired the normal structure and function of cardiomyocytes, leading to apoptosis [19].

Selenium (Se) is an essential trace mineral for animals and humans $[20,21]$. Se has antioxidant effects [22] and improves the body's immune system [23]. Se deficiency causes various diseases, such as hepatocellular carcinoma and muscular dystrophy [24-27]. Many studies have indicated that Se can alleviate toxicity induced by several heavy metals and drugs [28]. Se antagonized lead $\mathrm{Pb}$ )-induced over-expression of inflammatory cytokines in the peripheral blood lymphocytes of chickens [29]. In chicken splenic lymphocytes, Se partly attenuated Cdinduced immune toxicity by improving the expression of immune cytokines [30]. More recently, several reports have indicated that $\mathrm{Se}$ has protective effects against $\mathrm{Cd}$-induced apoptosis. In mice kidneys, Se markedly inhibited apoptosis attributed to Cd-induced mitochondrial dysfunction [30]. The alleviating effects of Se on Cd-induced apoptosis involved downregulating the expression of pro-apoptotic genes (Bak, p53, caspase 3 and caspase 9) and upregulating the expression of antiapoptotic genes (Bcl-2 and Bcl-x) [13, 31]. Moreover, Khera et al. suggested that Se supplementation increased the mitochondrial contents and increased the expression of mediators of mitochondrial biogenesis in cells [32]. Se was also found to alleviate $\mathrm{Cd}$-induced changes in tissues and mitochondria ultrastructure [33].

In summary, several previous studies have demonstrated that $\mathrm{Cd}$ induces apoptosis in various tissues and cells, and Se can relieve Cd toxicity. Nevertheless, the mechanisms underlying $\mathrm{Cd}$-induced apoptosis by disrupting mitochondrial dynamics and energy metabolism in chicken spleens and the antagonistic effects of Se are still unclear. The aim of this study was to investigate these mechanisms. We established the Se-Cd interaction model and examined the ultrastructural changes, frequency of apoptosis and expression of apoptosis-, immune-, mitochondrial dynamic- and energy metabolism-related genes in chicken spleens. With this study, we hope to provide a new perspective on the interaction of $\mathrm{Se}$ and Cd-induced apoptosis in chicken spleens.

\section{RESULTS}

\section{Ultrastructural changes}

Electron microscopy showed normal ultrastructure of chicken spleens in the control and Se-treated groups (Figure 1A-1B), with no obvious pathological changes. As shown in Figure 1D-1E, Cd treatment alone caused extensive splenic tissue damage. The apoptotic cells displayed morphological characteristics of apoptosis, including cell shrinkage, chromatin condensation, and margination. Furthermore, Cd treatment caused distinctly swollen mitochondria with degenerating or missing cristae. In the $\mathrm{Se}+\mathrm{Cd}$-treated group, slightly dilated cisternae of the smooth endoplasmic reticulum and swollen mitochondria were observed (Figure 1C).

\section{TdT-mediated dUTP nick end labeling (TUNEL) assay}

The number of apoptotic cells in chicken spleens was examined by the TUNEL assay. The apoptotic cells had brown-stained nuclei, and showed morphological changes such as condensed and irregular nuclei. As is presented in Figure 2A-2B, the number of apoptotic cells in spleens was similar between the control group and the Se-treated group. In the Cd-treated group, the number of apoptotic cells was evidently increased compared to the other groups (Figure 2C). Se supplementation during $\mathrm{Cd}$ exposure markedly reduced the frequency of apoptotic cells compared to the Cd-treated group (Figure 2D).

\section{The relative expression of apoptosis-related genes in chicken spleens}

The expression of apoptosis-related genes in chicken spleens is shown in Figure 3. Se treatment alone had no influence on apoptosis-related genes compared to those in the control group $(p>0.05)$. In the Cd-treated group, mRNA and protein levels of Bax, Bak, p53, Cyt-c, caspase 3 and caspase 9 were markedly increased and those of Bcl-2 were significantly decreased compared to the levels in the control group $(p<0.05)$. In the $\mathrm{Se}+\mathrm{Cd}$-treated group, we found that Se observably attenuated the changes induced by $\mathrm{Cd}$, but expression levels did not reach the control group levels $(p<0.05)$.

\section{The relative expression of immune-related genes in chicken spleens}

The expression of immune-related genes in chicken spleens is shown in Figure 4. There were no significant differences between the expression levels in the control group and the Se-treated group $(p>0.05)$. The relative mRNA levels of interlenkin-1 $\beta$ (IL-1 $\beta$ ) and tumor necrosis factor- $\alpha(\mathrm{TNF}-\alpha)$ were markedly higher, and interlenkin-2 
(IL-2), interferon- $\gamma$ (IFN- $\gamma$ ) levels were remarkably lower in the Cd-treated group than those in the control group $(p<0.05)$. Se and Cd co-treatment significantly attenuated the changes induced by $\mathrm{Cd}$, but did not bring the gene expression to the control group level $(p<0.05)$.

\section{The relative expression of mitochondrial dynamics-related genes in chicken spleens}

The effects of $\mathrm{Cd}$ and/or $\mathrm{Se}$ on the relative expression of mitochondrial dynamics-related genes in chicken spleens are shown in Figure 5. Se treatment alone did not influence the mitochondrial dynamics-related genes compared to the control group genes $(p>0.05)$. $\mathrm{Cd}$ treatment alone significantly decreased the mRNA and protein levels of Mfn1, Mfn2 and Opa1, and elevated the mRNA and protein levels of Drp1 and Mff, compared to the control group levels $(p<0.05)$. However, in the $\mathrm{Se}+\mathrm{Cd}$-treated group, we observed that Se remarkably decreased the mRNA and protein levels of Mff and Drp1, and increased the mRNA and protein levels of Opa1, Mfn2 and Mfn1 compared to the levels in the Cd-treated group $(p<0.05)$.

\section{The relative expression of energy metabolism- related genes in chicken spleens}

The relative expression of energy metabolismrelated genes in chicken spleens is shown in Figure 6. Se treatment alone did not influence the energy metabolismrelated genes compared to the control group genes $(p>0.05)$. Cd treatment alone remarkably decreased the expression of aconitase 2 (ACO2), hexokinase 1 (HK1), hexokinase 2 (HK2), lactate dehydrogenase A (LDHA), lactate dehydrogenase B (LDHB), PFK, pyruvate kinase (PK) and succinatedehydrogenase B (SDHB) compared to the expression levels in the other groups $(p<0.05)$. However, in the $\mathrm{Se}+\mathrm{Cd}$-treated group, the expression of ACO2, HK1, HK2, LDHA, LDHB, PFK, PK and SDHB was markedly increased compared to the $\mathrm{Cd}$-treated group expression levels $(p<0.05)$.

\section{DISCUSSION}

Apoptosis plays an important role in stabilizing the homeostatic system in organisms [34]. Because the spleen is a primary immune organ, excessive apoptosis in splenic cells may cause structural and functional damage to the spleen, leading to immune dysfunction. Many researchers have observed that $\mathrm{Cd}$ induces apoptosis in animals. For instance, in rats, $\mathrm{Cd}$ treatment increased the number of apoptotic cells in renal cortical tissues and brain $[35,36]$. In chicken, $\mathrm{Cd}$ induced apoptosis in the liver, leading to liver tissue damage [37]. In the present study, our results demonstrated that splenic cells with $\mathrm{Cd}$ treatment displayed typical morphological changes associated with apoptosis, and the frequency of apoptosis was markedly increased. However, Se was reported to
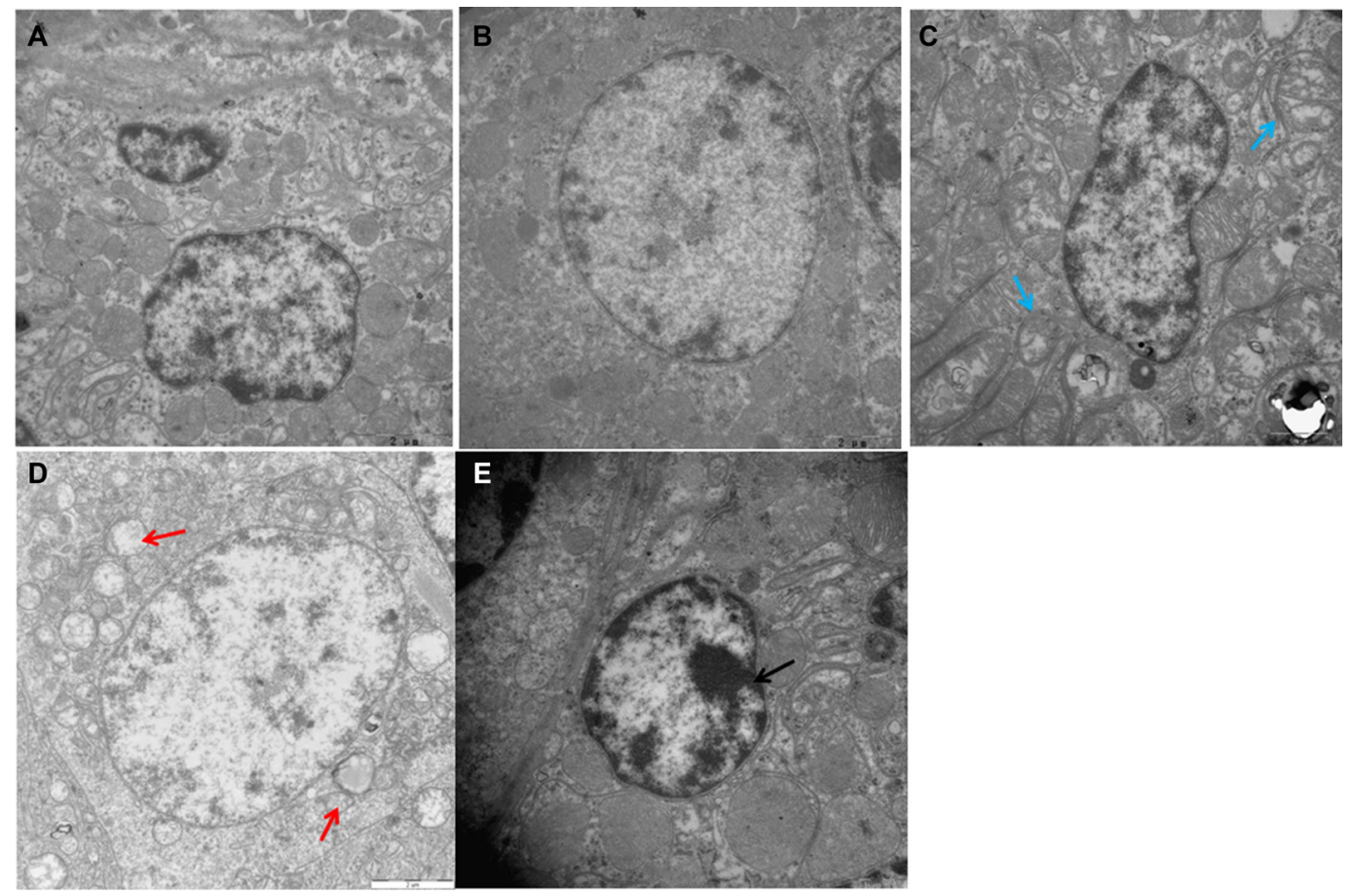

Figure 1: Ultrastructural changes in chicken spleens.(A) Spleens of the control group $(\times 15000)$. (B) Spleens of the Se-treated group $(\times 15000)$. (C) Spleens of the Se+Cd-treated group $(\times 15000)$. (D) Spleens of the Cd-treated group $(\times 15000)$. $(\mathbf{E}) \mathrm{Spleens}$ of the Cdtreated group $(\times 20000)$. Blue arrow displays slightly swollen mitochondria. Red arrow displays mitochondrial vacuolation. Black arrow displays chromatin condensation. 
have antagonistic effects on $\mathrm{Cd}$ toxicity in the immune organs of chicken [38]. Consistent with these studies, our results suggested that Se may significantly recover the normal structure of splenic cells, reduce the frequency of Cd-induced apoptotic cells, restore spleen function and enhance immune function.

Several studies have demonstrated that $\mathrm{Cd}$ has an immunosuppressive effect. IL-1 $\beta$, IL-2, TNF- $\alpha$ and IFN- $\gamma$ are important indexes of immune function [39-41]. Pb exposure increased the level of TNF- $\alpha$ $[42,43]$. Excessive $\mathrm{Mn}$ inhibited the expression of IL-2, causing immunosuppression in chicken splenic lymphocytes [43]. Our results demonstrated that the mRNA and protein levels of TNF- $\alpha$ and IL-1 $\beta$ were markedly increased and those of IL- 2 , IFN- $\gamma$ were significantly decreased following $\mathrm{Cd}$ treatment. These results support findings from previous studies and confirm that $\mathrm{Cd}$ induces immune dysfunction in chicken spleen. In addition, reports demonstrated that $\mathrm{Pb}$ toxicity was remarkably alleviated by $\mathrm{Se}$ treatment in the chicken liver [44]. Consistent with these reports, our results also demonstrated that Se supplements could rescue the abnormal expression of immune-related genes induced by $\mathrm{Cd}$, thereby improving immune function.

A recent study demonstrated that mitochondrial dynamic imbalances induced apoptosis [45]. Drp1, Mff, Mfn1, Mfn2 and Opa1 are associated with the mitochondrial dynamics equilibrium, and Drp1 and Mff play a major role in mitochondrial fission. Conversely, mitochondrial fusion is largely regulated by Mfn1, Mfn2 and Opa1. In addition, Drp1-dependent cristae remodeling amplify apoptosis [45]. Opa1 not only promotes mitochondrial fusion [46] but also regulates the cristae shape and remodeling to control Cyt-c release [47]. Studies have demonstrated that $\mathrm{CdCl}_{2}$ exposure increased Drp1 expression and enhanced mitochondrial recruitment, resulting in excessive mitochondrial fission [14]. The excessive mitochondrial fission led to mitochondrial
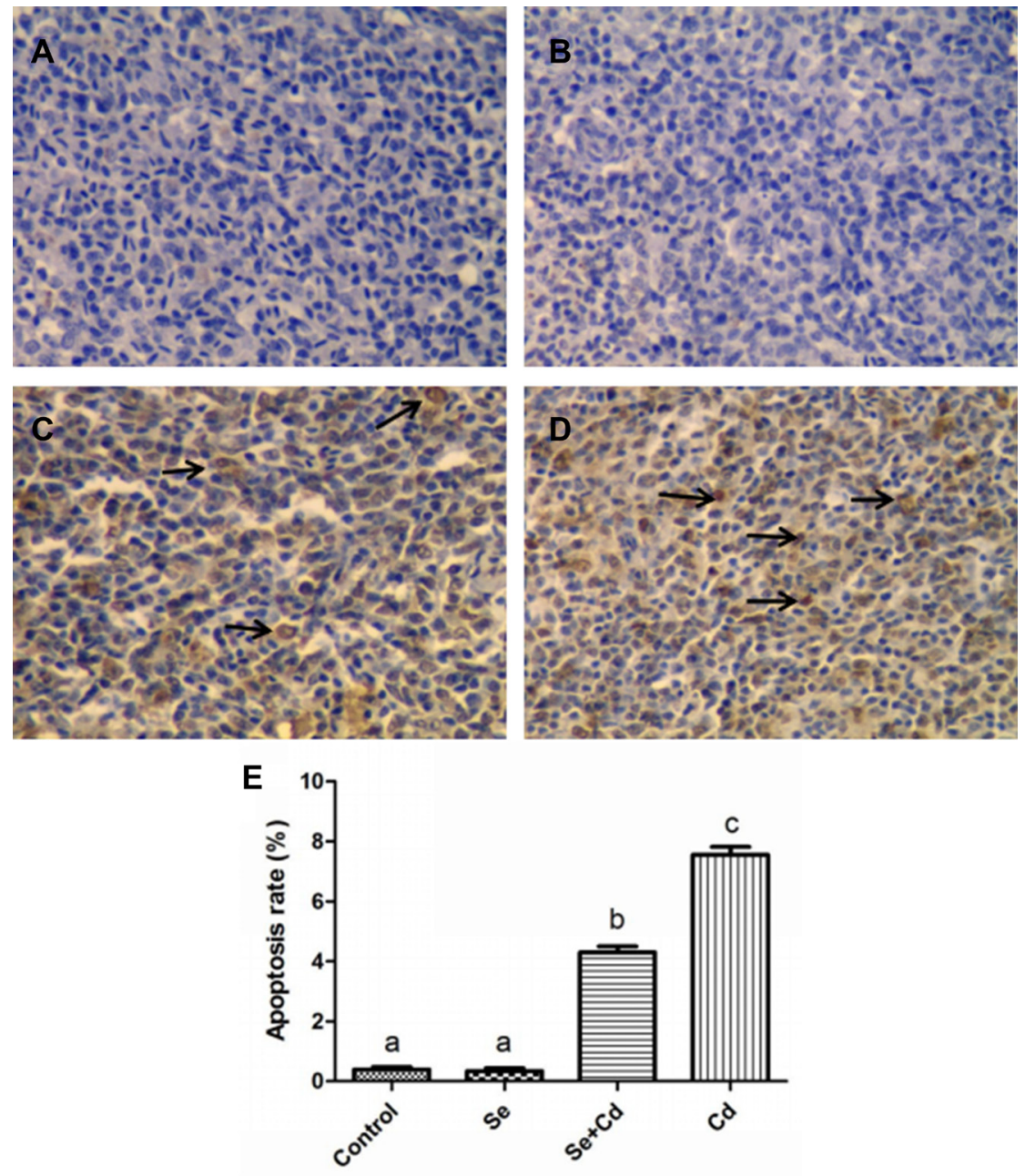

Figure 2: The frequency of apoptosis in chicken spleens detected by TUNEL assay. TUNEL staining (A-D): spleens of the control group, the Se-treated group, the $\mathrm{Se}+\mathrm{Cd}$-treated group, and the Cd-treated group. The magnification is $\times 400$ and the black arrow displays the apoptotic cells. (E) The percentage of the apoptotic cells. Each value represents the mean \pm SD. Bars not sharing a common letter are significantly different $(p<0.05)$. 


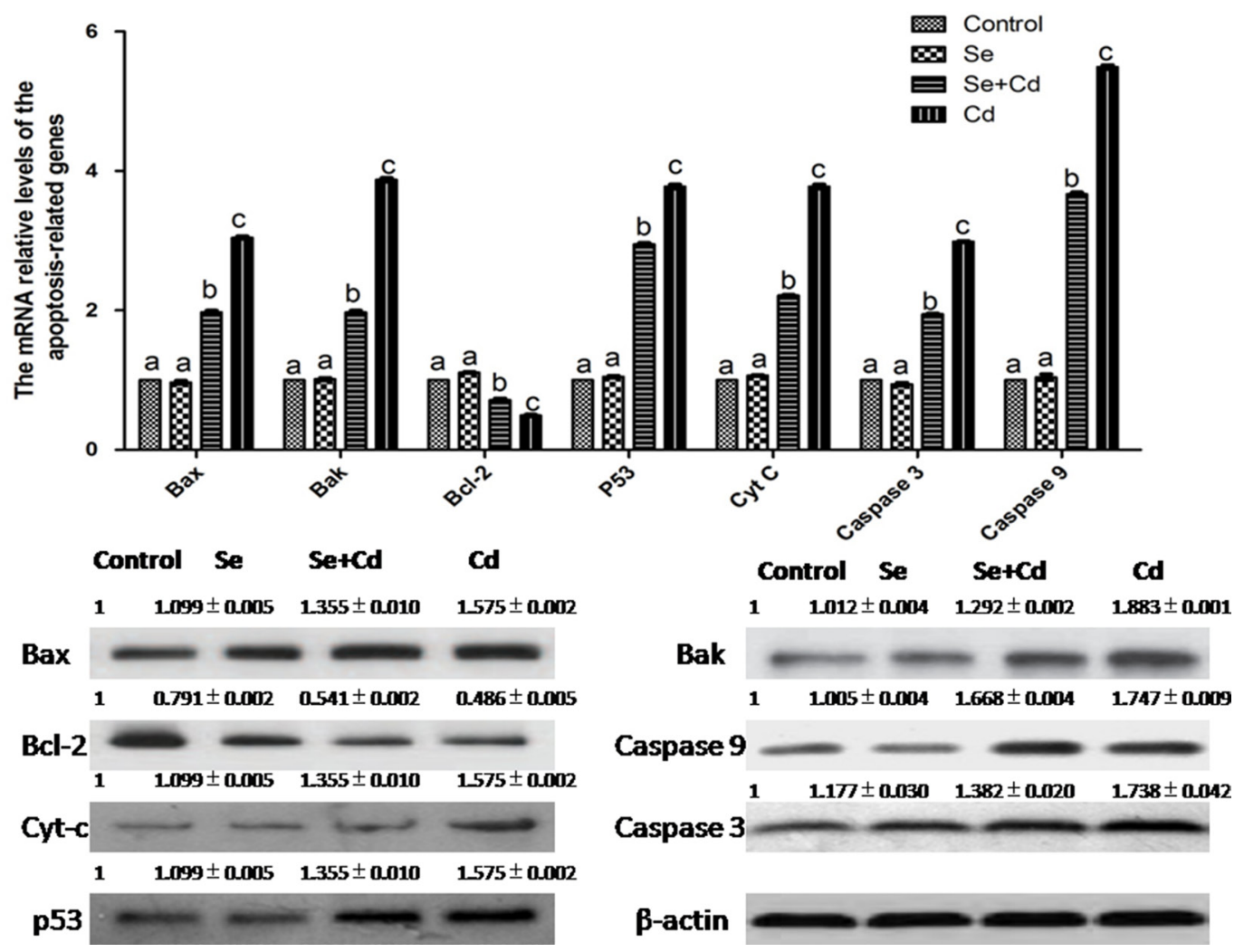

Figure 3: The relative mRNA and protein levels of apoptosis-related genes in chicken spleens. Effects of $\mathrm{Se}, \mathrm{Cd}$ and $\mathrm{Se}+\mathrm{Cd}$ treatment on the relative mRNA and protein levels of apoptosis-related genes were examined in chicken spleens. Chicken $\beta$-actin was used as an internal reference. Each value represents the mean $\pm \mathrm{SD}(n=10)$. Bars with different small letters represent statistically significant differences between the groups $(p<0.05)$; the bars with a common letter are not significantly different $(p>0.05)$.

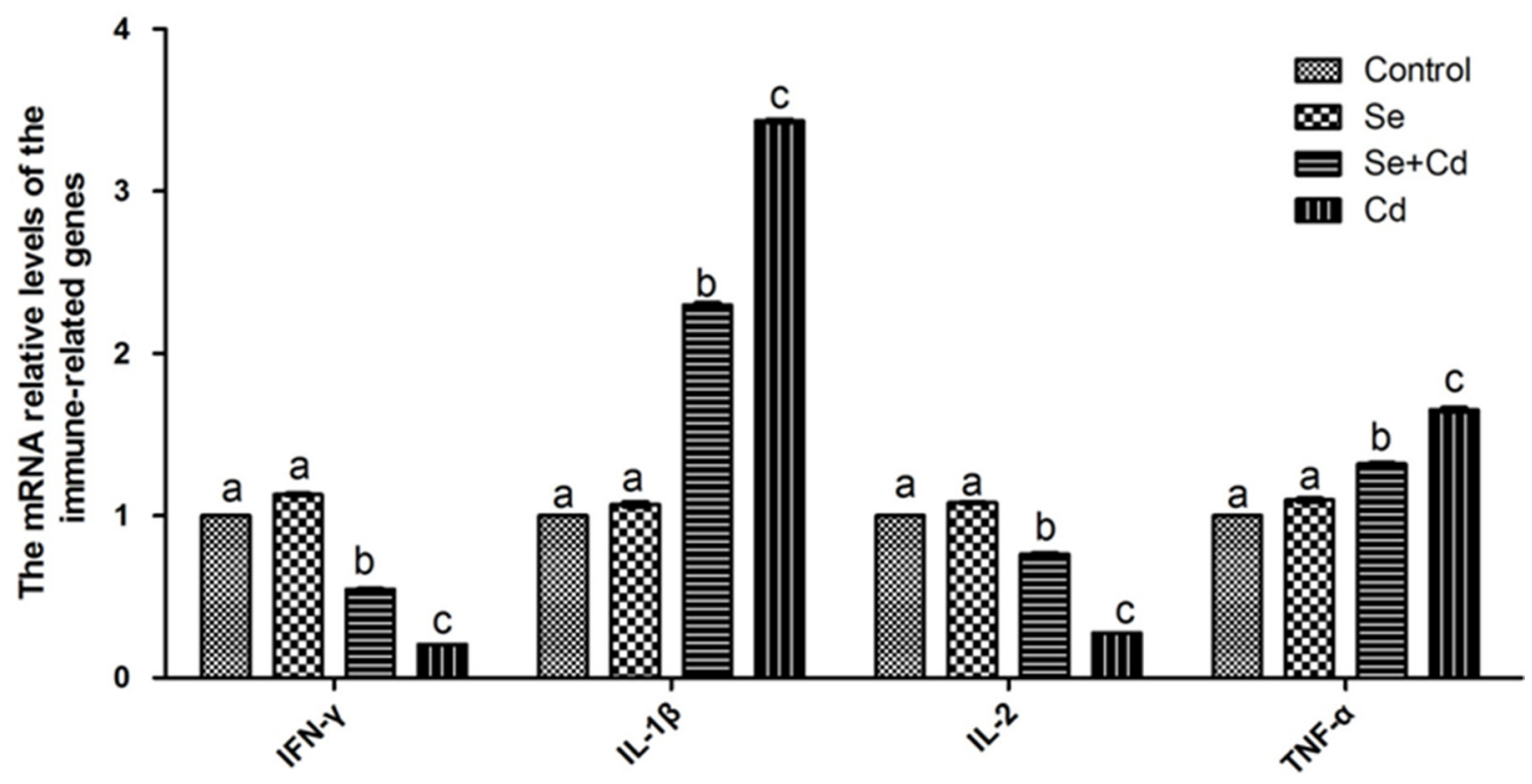

Figure 4: The relative mRNA levels of immune-related genes in chicken spleens. Effects of $\mathrm{Se}, \mathrm{Cd}$ and $\mathrm{Se}-\mathrm{Cd}$ treatment on the relative mRNA and protein levels of immune-related genes were examined in chicken spleens. Chicken $\beta$-actin was used as an internal reference. Each value represents the mean $\pm \mathrm{SD}(n=10)$. The bars with different small letters represent statistically significant differences between the groups $(p<0.05)$; the bars with a common letter are not significantly different $(p>0.05)$. 
fragmentation and mitochondrial structure damage, causing Cyt-c release [48]. Cyt-c, in turn, activated the caspase cascade, leading to apoptosis. Moreover, Drp1 promoted Bax mitochondrial translocation [49]. Bax and Bak also inhibited mitochondrial fusion by impinging on Mfn2 [50]. Bax and BcL-2 increased mitochondrial permeability and induced apoptosis. Samy et al. observed that the expression of Bax and Bak was markedly increased and that of Bcl-2 was decreased by $\mathrm{Cd}$ [51]. In addition, treatment with $\mathrm{Cd}$ increased the expression of p53 and caused apoptosis [52]. Consistent with the results of previous studies, we found that the expression of Drp1 and Mff was markedly enhanced and expression of Mfn1, Mfn2 and Opa1 was decreased in chicken spleens following $\mathrm{Cd}$ treatment. Evidently swollen mitochondria with degenerating or missing cristae were observed, and the expression of caspase 3, caspase 9 and p53 was markedly increased in the Cd-treated group. Previous studies revealed that Se supplements restored the normal structure of splenic cells [38] and prevented mitochondrial dynamic imbalance [53]. Our results are consistent with these results and demonstrate that $\mathrm{Se}$ suppressed expression of Drp1 and Mff and enhanced expression of Mfn1, Mfn2 and Opa1, consequently restoring mitochondrial dynamics equilibrium in chicken spleens. Furthermore, as described in a study by Liu [13], our results also demonstrated that Se markedly reduced Cd-induced apoptosis in chicken spleens by decreasing the expression of Bax and Bak and increasing the expression of Bcl-2.

Mitochondria are the primary sites for production of ATP. If mitochondrial function was impaired, the energy metabolism system would be in disorder. Because glycometabolism is the primary method to produce energy, many reports have investigated whether cell apoptosis via the mitochondrial pathway may be related to glycometabolism. In rats, ATP reduction induced by inhibiting glycometabolism triggered cell apoptosis [54]. In Panc-1 human pancreatic cancer cells, the apoptotic rate gradually increased due to blocked glycometabolism [55]. Evidence from previous studies suggests that HK2 depression inhibits human and mouse lung cancer cell growth by inducing cell apoptosis [56]. LDH inhibition also promoted apoptosis through enhancement of mitochondrial oxidative stress generation [57]. In our study, we detected the expression of a series of glycometabolism-related enzymes,

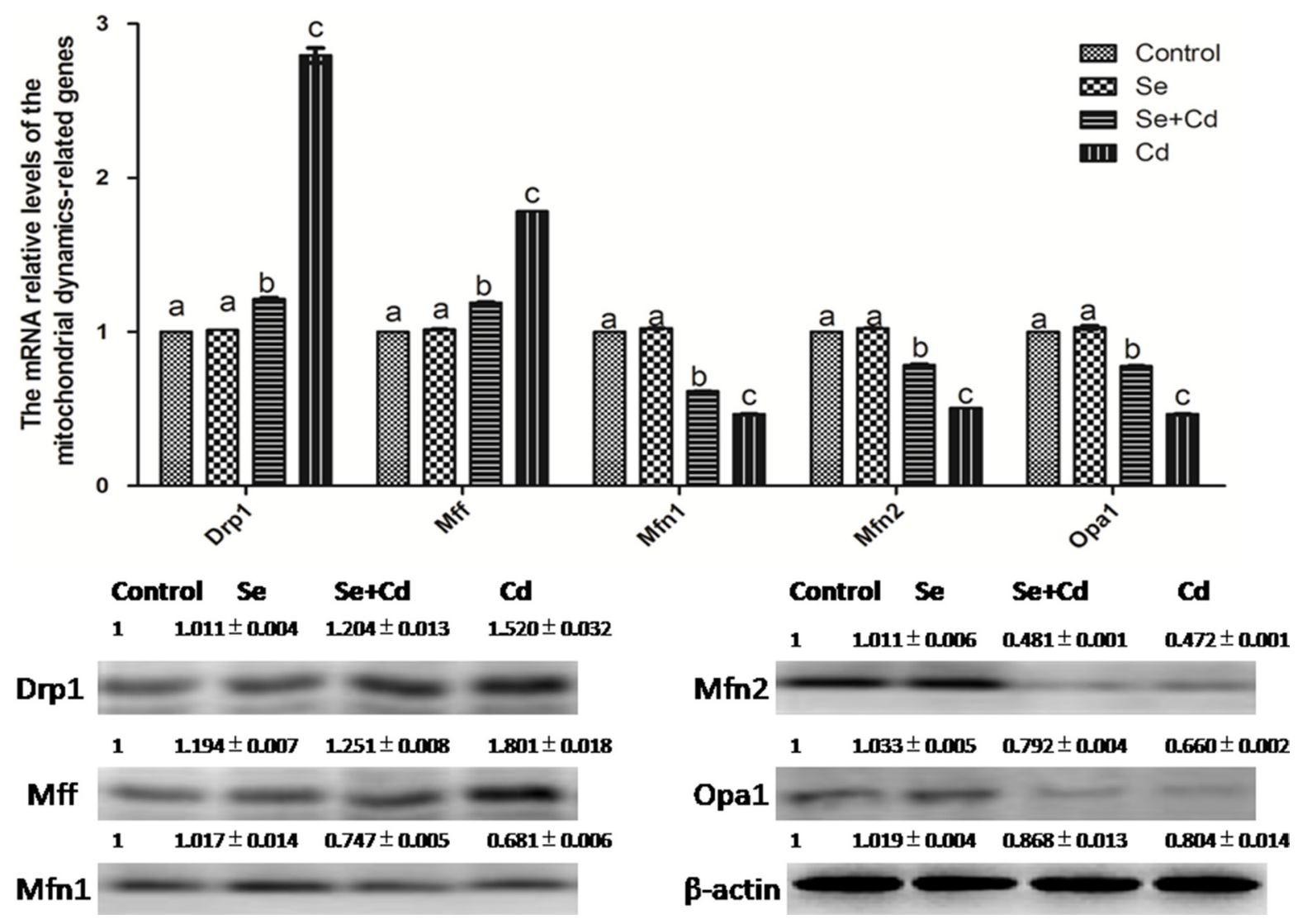

Figure 5: The relative mRNA and protein levels of mitochondrial dynamics-related genes in chicken spleens. Effects of $\mathrm{Se}, \mathrm{Cd}$ and $\mathrm{Se}+\mathrm{Cd}$ treatment on the relative mRNA and protein levels of mitochondrial dynamics-related genes were examined in chicken spleens. Chicken $\beta$-actin was used as an internal reference. Each value represents the mean $\pm \operatorname{SD}(n=10)$. The bars with different small letters represent statistically significant differences between the groups $(p<0.05)$; the bars with a common letter are not significantly different $(p>0.05)$. 
including LDHA, LDHB, HK1, HK2, PK, SDHB, PFK and $\mathrm{ACO}$. Consistent with previous findings, our results showed that the levels of all the glycometabolism-related enzymes detected were decreased with $\mathrm{Cd}$ treatment. Therefore, $\mathrm{Cd}$ inhibited both aerobic and anaerobic respiration by reducing the expression of glycometabolism-related genes, resulting in apoptosis in chicken spleens. Moreover, Lu reported that sodium selenite improved glycometabolism [58]. Our results are in support of previous research findings and confirm that Se improves glycometabolism by increasing the expression of LDHA, LDHB, HK1, HK2, PK, SDHB, PFK and ACO2 in chicken spleens.

In conclusion, we demonstrated that $\mathrm{Cd}$ induced excessive mitochondrial fragmentation, mitochondrial structure damage and reduced energy metabolism, leading to apoptosis and immune dysfunction in chicken spleens, and Se inhibited apoptosis by partially alleviating (Figure 7) these effects induced by $\mathrm{Cd}$. Our results enrich the understanding of the mechanism of apoptosis induced by $\mathrm{Se}$ and $\mathrm{Cd}$ interaction in chicken spleens.

\section{MATERIALS AND METHODS}

\section{Birds and experimental design}

The experiments were approved by the Institutional Animal Care and Use Committee of the Northeast Agricultural University under the approved protocol number SRM-06. We determined the Cd lethal dose (LD50) for chicken to be $218.44 \mathrm{mg} / \mathrm{kg} \mathrm{BW}$, and the doses and durations of $\mathrm{Cd}$ and Se used in this study have been described previously [59]. In brief, forty-eight 28-day-old Isa Brown male chickens were divided randomly into four groups ( $n=10$ per group). The remaining two chickens in each group were used as standby in case of any unexpected conditions. Group I (the control group) was fed a basal diet without Se or Cd supplementation (the Se content was $0.2 \mathrm{mg} / \mathrm{kg}$ ). Group II (the Se-treated group) was fed the basic diet supplemented with $\mathrm{Na}_{2} \mathrm{SeO}_{3}$; the total Se content was $2 \mathrm{mg} / \mathrm{kg}$. Group III (the $\mathrm{Se}+\mathrm{Cd}$-treated group) was fed the basic diet supplemented with $\mathrm{Na}_{2} \mathrm{SeO}_{3}$ (the total
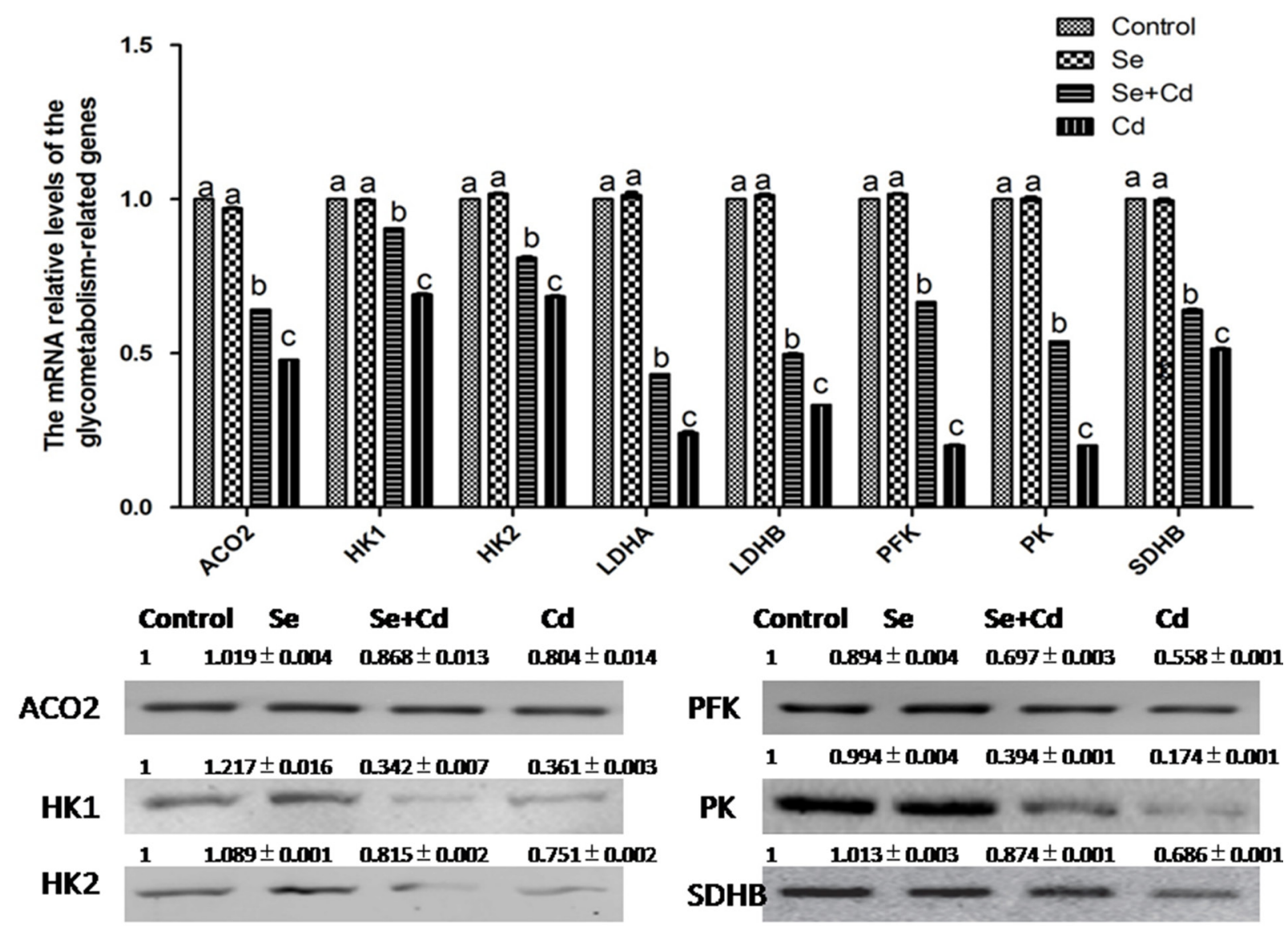

B-actin

Figure 6: The relative mRNA and protein levels of energy metabolism-related genes in chicken spleens. Effects of Se, $\mathrm{Cd}$ and $\mathrm{Se}+\mathrm{Cd}$ treatment on the relative mRNA and protein levels of energy metabolism-related genes were examined in chicken spleens. Chicken $\beta$-actin was used as an internal reference. Each value represents the mean $\pm \operatorname{SD}(n=10)$. The bars with different small letters represent statistically significant differences between the groups $(p<0.05)$; the bars with a common letter are not significantly different $(p>0.05)$. 
Se content was $2 \mathrm{mg} / \mathrm{kg}$ ) and $150 \mathrm{mg} / \mathrm{kg} \mathrm{CdCl}$. Group IV (the Cd-treated group) was fed the basic diet supplemented with $150 \mathrm{mg} / \mathrm{kg} \mathrm{CdCl}$. The duration of experiment was 90 days and the 10 chickens in each group were selected randomly for detection of experimental indexes. Following euthanasia, part of the spleen was examined by electron microscopy and the TUNEL assay, as described in the following sections. The remaining spleen was quickly removed and cleaned with ice-cold sterile deionized water, frozen immediately in liquid nitrogen, and stored at $-80^{\circ} \mathrm{C}$ until required for subsequent experiments.

\section{Transmission electron microscopy}

For electron microscopy, spleen tissue specimens (approximately $1 \mathrm{~mm}^{3}$ ) were rapidly fixed with 2.5 $\%$ glutaraldehyde in $0.1 \mathrm{M}$ sodium phosphate buffer (pH 7.2) for $3 \mathrm{~h}$ at $4^{\circ} \mathrm{C}$, washed in the same buffer for $1 \mathrm{~h}$ at $4^{\circ} \mathrm{C}$, and post-fixed with $1 \%$ osmium tetroxide in sodium phosphate buffer for $1 \mathrm{~h}$ at $4^{\circ} \mathrm{C}$. The tissues were then dehydrated in a graded series of ethanol, starting at $50 \%$ for $10 \mathrm{~min}$ at each step, followed by two changes in propylene oxide. The tissue specimens were embedded in Araldite. Ultrathin sections were stained with $\mathrm{Mg}$ uranyl acetate and lead citrate for transmission electron microscope evaluation (GEM-1200ES, Japan).

\section{TUNEL assay}

TUNEL detection of apoptotic cells was performed in formalin-fixed, paraffin-embedded spleen tissue sections according to the manufacturer's protocol (Roche, USA). This procedure distinguishes apoptotic cells from those undergoing necrosis because damaged DNA in apoptotic cells leads to a different distribution of staining and nuclear morphology. Paraffin wax-embedded tissue sections were treated with proteinase $\mathrm{K}$, and the endogenous peroxidase activity was blocked with hydrogen peroxide. The sections were incubated at $37^{\circ} \mathrm{C}$ with the terminal TdT/ nucleotide mixture for $1 \mathrm{~h}$. Next, the reaction was stopped and the slides were rinsed with phosphate-buffered saline (PBS). Nuclear labeling was developed with horseradish peroxidase and diaminobenzidine. Hematoxylin was used for counterstaining.

\section{Quantitative real time-polymerase chain reaction}

Total RNA was isolated from tissue samples using the TRIzol reagent according to the manufacturer's instructions (Invitrogen, Carlsbad, USA). The RNA concentrations were determined using the GeneQuant 1300. The procedure for reverse transcription was performed according to the manufacturer's instructions

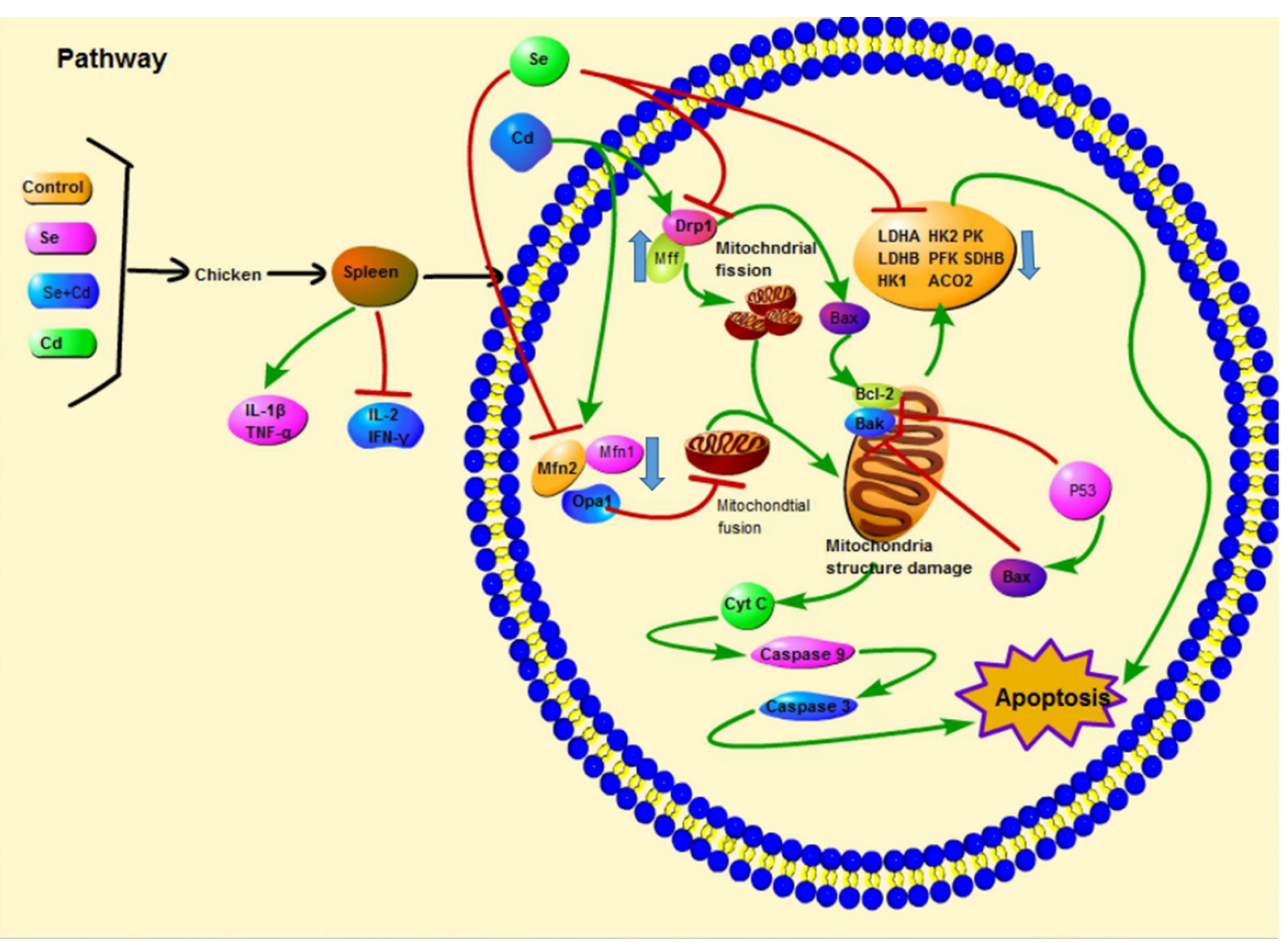

Figure 7: Scheme shows the pathway of Se and Cd interaction and the Cd-induced apoptosis in chicken spleens. Scheme shows the mechanism of Cd-induced apoptosis by disturbing mitochondrial dynamics and energy metabolism in chicken spleens and the antagonistic effects of Se. The green line displays the promotion and the red line displays the inhibition. 
Table 1: Gene-specific primers used in the real-time quantitative reverse transcription PCR experiments

\begin{tabular}{|c|c|c|c|}
\hline Gene & Primer $\left(5^{\prime}-3^{\prime}\right)$ & Gene & Primer $\left(5^{\prime}-3^{\prime}\right)$ \\
\hline \multirow{2}{*}{ Mff } & F:TGGGAAGGCTGAAGAGAGAA & \multirow{2}{*}{ Drp1 } & F:GGCAGTCACAGCAGCTAACA \\
\hline & R:GGTGTTCCCTCAAGTGTGGT & & R:GCATCCATGAGATCCAGCTT \\
\hline \multirow{2}{*}{ Opa1 } & F:GCTACGGACCAGGGTTATGA & \multirow{2}{*}{ Mfn1 } & F:TGAGCATGTAGCAACGGAAG \\
\hline & R:GCTCAAGCATCCGTTGGTAT & & R:AGCAAGCTGATTGACGGTCT \\
\hline \multirow{2}{*}{ Mfn2 } & F:TACCAGGCAGATTTCCATCC & \multirow{2}{*}{ IFN- $\gamma$} & F:AGCCGCACATCAAACACATA \\
\hline & R:GTGATTGCATTGGAACAACG & & R:CGCTGGATTCTCAAGTCGTT \\
\hline \multirow{2}{*}{ TNF- $\alpha$} & F:AGATGGGAAGGGAATGAACC & \multirow{2}{*}{ IL-1 $\beta$} & F:CTCCTCCAGCCAGAAAGTGA \\
\hline & R:ACTGGGCGGTCATAGAACAG & & R:GAGCTTGTAGCCCTTGATGC \\
\hline \multirow{2}{*}{ IL-2 } & F:TGCAGTGTTACCTGGGAGAA & \multirow{2}{*}{$\beta$-actin } & F:ACGTCGCACTGGATTTCGAG \\
\hline & R:CGGTGTGATTTAGACCCGTAA & & R:TGTCAGCAATGCCAGGGTAC \\
\hline \multirow{2}{*}{ PK } & F:GAACTGCGATGAGAATGTGC & \multirow{2}{*}{ HK2 } & F:CCCAGATAGAAAGCGACTGC \\
\hline & R:ACCAGCAAGGAAATGAGACC & & R:ACCTCCTTGACGATGATGCT \\
\hline \multirow{2}{*}{ SDHB } & F:GCTGCGGCCGATCTGT & \multirow{2}{*}{ PFK } & F:GAGCCACCTGAACATCGTG \\
\hline & R:GCTTGTCCCCAGGCTTATCA & & R:CATCACTTCCAGCACAAACG \\
\hline \multirow{2}{*}{ HK1 } & F:ACTTCACCAAACGAGGGTTC & \multirow{2}{*}{ LDHA } & F:CATCACTTCCAGCACAAACG \\
\hline & R:CCTGTCGCTCTCAATCTGTG & & R:CGGTGTTTAGGAAAGCCACT \\
\hline \multirow{2}{*}{ LDHB } & F:AAGCAGGTTGTTGAAAGTGC & \multirow{2}{*}{$\mathrm{ACO} 2$} & F:GCCAAGGACATAAACCAGGA \\
\hline & R:AAGGCAGGCTCAGGAAGAC & & R:TGTGAGTCTGTGCCAATCAAC \\
\hline \multirow{2}{*}{ Bax } & F:TATGGGACACCAGGAGGGTA & \multirow{2}{*}{ Bak } & F: ACCCGGAGATCATGGAGA \\
\hline & R:CGTAGACCTTGCGGATAAAGC & & R:GATGCCTTGCTGGTAGACG \\
\hline \multirow{2}{*}{ P53 } & F:CCCATCCTCACCATCCTТACA & \multirow{2}{*}{$\mathrm{Bcl}-2$} & F:ATCGTCGCCTTCTTCGAGTT \\
\hline & R:CTCGATCTTGCGGTCCCTC & & R:CTGACTATCACCAAGAACCACC \\
\hline \multirow{2}{*}{ Caspase 3} & F:CTGAAGGCTCCTGGTTTA & \multirow{2}{*}{ Caspase 9} & F:CCGAAGGAGCAAGCACG \\
\hline & R:CTCGATCTTGCGGTCCCTC & & R:AGGTTGGACTGGGATGGAC \\
\hline \multirow{2}{*}{ Cty-c } & F:AGGCAAGCACAAGACTGGA & & \\
\hline & R:CTGACTATCACCAAGAACCACC & & \\
\hline
\end{tabular}

(Roche, Basel, Switzerland). Synthesized cDNA was stored at $-20^{\circ} \mathrm{C}$ for PCR. Oligo 6.0 software was used to design specific primers based on known sequences (Table 1). Chicken $\beta$-actin was used as a housekeeping gene and an internal reference. Primers were synthesized by Invitrogen Biotechnology Co. Ltd. in Shanghai, China.

QRT-PCR was performed on a LightCycler ${ }^{\circledR} 480$ Detection System (Roche, Basel, Switzerland) using Fast Universal SYBR Green Master (Roche, Basel, Switzerland). The program was run as follows: 1 cycle at $95^{\circ} \mathrm{C}$ for $30 \mathrm{~s}$ followed by 40 cycles at $95^{\circ} \mathrm{C}$ for $5 \mathrm{~s}$ and at $60^{\circ} \mathrm{C}$ for $34 \mathrm{~s}$. Dissociation curves for each PCR reaction were analyzed by using the Dissociation Curve 1.0 software (Applied Biosystems) to detect and eliminate possible primer-dimers and non-specific amplifications. The relative abundance of mRNA was calculated according to the method of Pfaffl [60].

\section{Western blot analysis}

Equal amounts of total protein $(40 \mu \mathrm{g})$ were subjected to $12 \%$ SDS-polyacrylamide gel electrophoresis under reducing conditions. The separated proteins were then transferred to nitrocellulose membranes using a tank transfer for $2 \mathrm{~h}$ at $200 \mathrm{~mA}$ in Tris-glycine buffer containing $20 \%$ methanol. Membranes were blocked with $5 \%$ skim milk for $24 \mathrm{~h}$ and incubated overnight with diluted primary antibodies against Bcl-2, Bak, Bax, Cyt-c (1:500, Santa Cruz Biotechnology, USA), Mff, Drp1, Mfn1, Mfn2, Opa1 (1:500, Proteintech, Chicago, IL, USA), caspase 3, caspase 9, p53, PK, HK1, HK2, AOC2, SDHB and PFK (1:1000, Santa Cruz Biotechnology, CA USA). Bound primary antibodies were detected with a horseradish peroxidase (HRP) conjugated secondary antibody against rabbit $\operatorname{IgG}$ (1:1500, Santa Cruz, CA, USA). To 
verify equal loading of the samples, the membrane was incubated with a monoclonal $\beta$-actin antibody (1:1000, Santa Cruz, CA, USA), followed by incubation with an HRP conjugated goat anti-mouse IgG (1:1000). The signal was measured by enhanced chemiluminescence detection reagents (Applygen Technologies Inc., Beijing, China). Protein bands were visualized using a ChampChemi imaging system (Beijing Sage Creation Science Co. Ltd., Beijing, China). The relative abundances of the proteins were expressed as the ratios of optical density of each of these proteins to that of $\beta$-actin.

\section{Statistical analysis}

Statistical analyses of all data were performed using SPSS for Windows (version 21.0; SPSS Inc., Chicago, IL, USA). One-way analysis of variance followed by the Tukey's honest significant difference test was used to analyze the descriptive statistics (mean values, standard deviation). The results were considered to be significant when $p<0.05$.

\section{Abbreviations}

Se, selenium; Cd, cadmium; BW, body weight; HK1, hexokinase 1; HK2, hexokinase 2; LDHA, lactate dehydrogenase A; LDHB, lactate dehydrogenase B; ACO2, aconitase 2; PK, pyruvate kinase; PFK, phosphofructokinase; SDHB, succinatedehydrogenase B; IL-1 $\beta$, interlenkin-1 $\beta$; IL-2, interlenkin-2; TNF- $\alpha$, tumor necrosis factor- $\alpha$; IFN- $\gamma$, interferon- $\gamma$; MFF, mitochondrial fission factor; Drp1, dynamin-related protein 1; Opa1, optic atrophy 1; Mfn1, mitofusin 1; Mfn2, mitofusin 2; Cyt-c, cytochrome c; ROS, reactive oxygen species; $\mathrm{Mn}$, manganese; $\mathrm{Pb}$, lead.

\section{ACKNOWLEDGMENTS}

We are thankful for the support of Heilongjiang Key Laboratory for Laboratory Animals and Comparative Medicine.

\section{CONFLICTS OF INTEREST}

The authors declare that they have no conflicts of interest.

\section{FUNDING}

This study received support from the National Natural Science Foundation of China (Grant No. 31472161).

\section{REFERENCES}

1. Alghasham A, Salem TA, Meki AR. Effect of cadmiumpolluted water on plasma levels of tumor necrosis factor- $\alpha$, interleukin-6 and oxidative status biomarkers in rats: protective effect of curcumin. Food Chem Toxicol. 2013; 59:160-64. https://doi.org/10.1016/j.fct.2013.05.059.

2. Liu D, Yang J, Li Y, Zhang M, Wang L. Cd-induced apoptosis through the mitochondrial pathway in the hepatopancreas of the freshwater crab Sinopotamon henanense. PLoS One. 2013; 8:e68770. https://doi. org/10.1371/journal.pone.0068770.

3. Zhao P, Guo Y, Zhang W, Chai H, Xing H, Xing M. Neurotoxicity induced by arsenic in Gallus Gallus: regulation of oxidative stress and heat shock protein response. Chemosphere. 2017; 166:238-45. https://doi. org/10.1016/j.chemosphere.2016.09.060.

4. Xiao Q, Zhang C, Gu X, Zhuang Y, Luo J, Liu P, Guo X, $\mathrm{Hu}$ G, Cao H. Varying dietary levels of molybdenum inducing cell apoptosis of spleen under cadmium stress in caprine. Biol Trace Elem Res. 2016; 172:127-33. https:// doi.org/10.1007/s12011-015-0565-3.

5. Guo Y, Zhao P, Guo G, Hu Z, Tian L, Zhang K, Sun Y, Zhang X, Zhang W, Xing M. Effects of arsenic trioxide exposure on heat shock protein response in the immune organs of chickens. Biol Trace Elem Res. 2016; 169:134-41. https://doi.org/10.1007/s12011-015-0389-1.

6. Hu D, Zou H, Han T, Xie J, Dai N, Zhuo L, Gu J, Bian J, Yuan Y, Liu X, Liu Z. Gap junction blockage promotes cadmium-induced apoptosis in BRL 3A derived from Buffalo rat liver cells. J Vet Sci. 2016; 17:63-70. https:// doi.org/10.4142/jvs.2016.17.1.63.

7. Liu L, Yang B, Cheng Y, Lin H. Ameliorative effects of selenium on cadmium-induced oxidative stress and endoplasmic reticulum stress in the chicken kidney. Biol Trace Elem Res. 2015; 167:308-19. https://doi.org/10.1007/ s12011-015-0314-7.

8. Wang L, Cao J, Chen D, Liu X, Lu H, Liu Z. Role of oxidative stress, apoptosis, and intracellular homeostasis in primary cultures of rat proximal tubular cells exposed to cadmium. Biol Trace Elem Res. 2009; 127:53-68. https:// doi.org/10.1007/s12011-008-8223-7.

9. Wang L, Chen D, Cao J, Liu Z. Protective effect of N-acetylcysteine on experimental chronic cadmium nephrotoxicity in immature female rats. Hum Exp Toxicol. 2009; 28:221-29. https://doi. org/10.1177/0960327109102365.

10. Ben P, Zhang Z, Xuan C, Sun S, Shen L, Gao Y, Cao X, Zhou Y, Lan L, Yin Z, Luo L. Protective Effect of L-theanine on cadmium-induced apoptosis in PC12 cells by inhibiting the mitochondria-mediated pathway. Neurochem Res. 2015; 40:1661-70. https://doi.org/10.1007/s11064-015-1648-4.

11. Yuan Y, Wang Y, Hu FF, Jiang CY, Zhang YJ, Yang JL, Zhao SW, Gu JH, Liu XZ, Bian JC, Liu ZP. Cadmium activates reactive oxygen species-dependent $\mathrm{AKT} / \mathrm{mTOR}$ and mitochondrial apoptotic pathways in neuronal cells. Biomed Environ Sci. 2016; 29:117-26. https://doi.org/10.3967/ bes2016.013. 
12. Chang KC, Hsu CC, Liu SH, Su CC, Yen CC, Lee MJ, Chen KL, Ho TJ, Hung DZ, Wu CC, Lu TH, Su YC, Chen YW, Huang CF. Cadmium induces apoptosis in pancreatic $\beta$-cells through a mitochondria-dependent pathway: the role of oxidative stress-mediated c-Jun N-terminal kinase activation. PLoS One. 2013; 8:e54374. https://doi. org/10.1371/journal.pone.0054374.

13. Liu S, Xu FP, Yang ZJ, Li M, Min YH, Li S. Cadmiuminduced injury and the ameliorative effects of selenium on chicken splenic lymphocytes: mechanisms of oxidative stress and apoptosis. Biol Trace Elem Res. 2014; 160:340-51. https://doi.org/10.1007/s12011-014-0070-0.

14. Xu S, Pi H, Chen Y, Zhang N, Guo P, Lu Y, He M, Xie J, Zhong M, Zhang Y, Yu Z, Zhou Z. Cadmium induced Drp1-dependent mitochondrial fragmentation by disturbing calcium homeostasis in its hepatotoxicity. Cell Death Dis. 2013; 4:e540. https://doi.org/10.1038/cddis.2013.7.

15. Pi H, Xu S, Zhang L, Guo P, Li Y, Xie J, Tian L, He M, Lu Y, Li M, Zhang Y, Zhong M, Xiang Y, et al. Dynamin 1-like-dependent mitochondrial fission initiates overactive mitophagy in the hepatotoxicity of cadmium. Autophagy. 2013; 9:1780-800. https://doi.org/10.4161/auto.25665.

16. Alaimo A, Gorojod RM, Miglietta EA, Villarreal A, Ramos AJ, Kotler ML. Manganese induces mitochondrial dynamics impairment and apoptotic cell death: a study in human Gli36 cells. Neurosci Lett. 2013; 554:76-81. https:// doi.org/10.1016/j.neulet.2013.08.061.

17. Brooks C, Cho SG, Wang CY, Yang T, Dong Z. Fragmented mitochondria are sensitized to Bax insertion and activation during apoptosis. Am J Physiol Cell Physiol. 2011; 300:C447-55. https://doi.org/10.1152/ajpcell.00402.2010.

18. Ramírez-Bajo MJ, de Atauri P, Ortega F, Westerhoff HV, Gelpí JL, Centelles JJ, Cascante M. Effects of cadmium and mercury on the upper part of skeletal muscle glycolysis in mice. PLoS One. 2014; 9:e80018. https://doi.org/10.1371/ journal.pone. 0080018 .

19. Chen CY, Zhang SL, Liu ZY, Tian Y, Sun Q. Cadmium toxicity induces ER stress and apoptosis via impairing energy homoeostasis in cardiomyocytes. Biosci Rep. 2015; 35:e00214. https://doi.org/10.1042/BSR20140170.

20. Cao C, Fan R, Zhao J, Zhao X, Yang J, Zhang Z, Xu S. Impact of exudative diathesis induced by selenium deficiency on LncRNAs and their roles in the oxidative reduction process in broiler chick veins. Oncotarget. 2017; 8:20695-705. https://doi.org/10.18632/oncotarget.14971.

21. Jin $\mathrm{X}, \mathrm{Xu} \mathrm{Z}, \mathrm{Zhao} \mathrm{X}$, Chen $\mathrm{M}, \mathrm{Xu} \mathrm{S}$. The antagonistic effect of selenium on lead-induced apoptosis via mitochondrial dynamics pathway in the chicken kidney. Chemosphere. 2017; 180:259-66. https://doi.org/10.1016/j. chemosphere.2017.03.130.

22. Yao HD, Wu Q, Zhang ZW, Li S, Wang XL, Lei XG, Xu SW. Selenoprotein W serves as an antioxidant in chicken myoblasts. Biochim Biophys Acta. 2013; 1830:3112-20. https://doi.org/10.1016/j.bbagen.2013.01.007.
23. El-Boshy ME, Risha EF, Abdelhamid FM, Mubarak MS, Hadda TB. Protective effects of selenium against cadmium induced hematological disturbances, immunosuppressive, oxidative stress and hepatorenal damage in rats. J Trace Elem Med Biol. 2015; 29:104-10. https://doi.org/10.1016/j. jtemb.2014.05.009.

24. Liu $\mathrm{C}, \mathrm{Fu}$ J, Liu C, Li S. The role of nitric oxide and autophagy in liver injuries induced by selenium deficiency in chickens. RSC Advances. 2015; 5:50549-56. https://doi. org/10.1039/C5RA01030F.

25. Yao HD, Wu Q, Zhang ZW, Zhang JL, Li S, Huang JQ, Ren FZ, Xu SW, Wang XL, Lei XG. Gene expression of endoplasmic reticulum resident selenoproteins correlates with apoptosis in various muscles of se-deficient chicks. J Nutr. 2013; 143:613-19. https://doi.org/10.3945/jn.112.172395.

26. Wang H, Li TL, Hsia S, Su IL, Chan YL, Wu CJ. Skeletal muscle atrophy is attenuated in tumor-bearing mice under chemotherapy by treatment with fish oil and selenium. Oncotarget. 2015; 6:7758-73. https://doi.org/10.18632/ oncotarget.3483.

27. Yao H, Fan R, Zhao X, Zhao W, Liu W, Yang J, Sattar H, Zhao J, Zhang Z, Xu S. Selenoprotein W redox-regulated $\mathrm{Ca} 2$ channels correlate with selenium deficiency-induced muscles Ca2 leak. Oncotarget. 2016; 7:57618-32. https:// doi.org/10.18632/oncotarget.11459.

28. $\mathrm{Hu} \mathrm{Y}$, Spengler ML, Kuropatwinski KK, ComasSoberats M, Jackson M, Chernov MV, Gleiberman AS, Fedtsova N, Rustum YM, Gudkov AV, Antoch MP. Selenium is a modulator of circadian clock that protects mice from the toxicity of a chemotherapeutic drug via upregulation of the core clock protein, BMAL1. Oncotarget. 2011; 2:1279-90. https://doi.org/10.18632/oncotarget.411.

29. Sun GX, Chen Y, Liu CP, Li S, Fu J. Effect of selenium against lead-induced damage on the gene expression of heat shock proteins and inflammatory cytokines in peripheral blood lymphocytes of chickens. Biol Trace Elem Res. 2016; 172:474-80. https://doi.org/10.1007/s12011-015-0602-2.

30. Xu F, Liu S, Li S. Effects of selenium and cadmium on changes in the gene expression of immune cytokines in chicken splenic lymphocytes. Biol Trace Elem Res. 2015; 165:214-21. https://doi.org/10.1007/s12011-015-0254-2.

31. Liu LL, Zhang JL, Zhang ZW, Yao HD, Sun G, Xu SW. Protective roles of selenium on nitric oxide-mediated apoptosis of immune organs induced by cadmium in chickens. Biol Trace Elem Res. 2014; 159:199-209. https:// doi.org/10.1007/s12011-014-0007-7.

32. Khera A, Dong L-f, Holland O, Vanderlelie J, Pasdar EA, Neuzil J, Perkins AV. Selenium supplementation induces mitochondrial biogenesis in trophoblasts. Placenta. 2015; 36:863-9. https://doi.org/10.1016/j.placenta.2015.06.010.

33. Li JL, Jiang CY, Li S, Xu SW. Cadmium induced hepatotoxicity in chickens (Gallus domesticus) and ameliorative effect by selenium. Ecotoxicol Environ Saf. 2013; 96:103-9. https://doi.org/10.1016/j.ecoenv.2013.07.007. 
34. Pu J, Tian G, Li B, Chen D, He J, Zheng P, Mao X, Yu J, Huang Z, Yu B. Trace mineral overload induced hepatic oxidative damage and apoptosis in pigs with longterm high-level dietary mineral exposure. J Agric Food Chem. 2016; 64:1841-49. https://doi.org/10.1021/acs. jafc.5b05613.

35. Erboga M, Kanter M, Aktas C, Sener U, Fidanol Erboga Z, Bozdemir Donmez Y, Gurel A. Thymoquinone ameliorates cadmium-induced nephrotoxicity, apoptosis, and oxidative stress in rats is based on its anti-apoptotic and anti-oxidant properties. Biol Trace Elem Res. 2016; 170:165-72. https:// doi.org/10.1007/s12011-015-0453-x.

36. Chen S, Ren Q, Zhang J, Ye Y, Zhang Z, Xu Y, Guo M, Ji H, $\mathrm{Xu} \mathrm{C}, \mathrm{Gu} \mathrm{C}$, Gao W, Huang S, Chen L. N-acetyl-L-cysteine protects against cadmium-induced neuronal apoptosis by inhibiting ROS-dependent activation of Akt/mTOR pathway in mouse brain. Neuropathol Appl Neurobiol. 2014; 40:759-77. https://doi.org/10.1111/nan.12103.

37. Zhang R, Yi R, Bi Y, Xing L, Bao J, Li J. The effect of selenium on the Cd-induced apoptosis via NO-mediated mitochondrial apoptosis pathway in chicken liver. Biol Trace Elem Res. 2017; 178:310-19. https://doi.org/10.1007/ s12011-016-0925-7.

38. Bao R, Wang X, Zheng S, Zhang Q, Lin H, Li S. Selenium supplementation changes the ion profile in the pancreas of chickens treated with cadmium. Biol Trace Elem Res. 2017 2017 Apr 27. https://doi.org/10.1007/s12011-017-1034-y.

39. Jameel A, Ooi KGJ, Jeffs NR, Galatowicz G, Lightman SL, Calder VL. Statin Modulation of Human T-Cell Proliferation, IL-1 $\beta$ and IL-17 Production, and IFN- $\gamma$ T Cell Expression: Synergy with Conventional Immunosuppressive Agents. Int J Inflam. 2013; 2013:434586. https://doi.org/10.1155/2013/434586.

40. Malek TR, Yu A, Zhu L, Matsutani T, Adeegbe D, Bayer AL. IL-2 family of cytokines in T regulatory cell development and homeostasis. J Clin Immunol. 2008; 28:635-39. https://doi.org/10.1007/s10875-008-9235-y.

41. Choi IK, Li Y, Oh E, Kim J, Yun CO. Oncolytic adenovirus expressing IL-23 and p35 elicits IFN- $\gamma$ - and TNF- $\alpha$-coproducing $\mathrm{T}$ cell-mediated antitumor immunity. PLoS One. 2013; 8:e67512. https://doi.org/10.1371/journal. pone.0067512.

42. Surh YJ, Chun KS, Cha HH, Han SS, Keum YS, Park KK, Lee SS. Molecular mechanisms underlying chemopreventive activities of anti-inflammatory phytochemicals: down-regulation of COX-2 and iNOS through suppression of NF- $\kappa \mathrm{B}$ activation. Mutat Res. 2001; 480-481:243-68. https://doi.org/10.1016/S00275107(01)00183-X.

43. Li X, Xing M, Chen M, Zhao J, Fan R, Zhao X, Cao C, Yang J, Zhang Z, Xu S. Effects of selenium-lead interaction on the gene expression of inflammatory factors and selenoproteins in chicken neutrophils. Ecotoxicol Environ Saf. 2017; 139:447-53. https://doi.org/10.1016/j. ecoenv.2017.02.017.
44. Xu T, Gao X, Liu G. The antagonistic effect of selenium on lead toxicity is related to the ion profile in chicken liver. Biol Trace Elem Res. 2016; 169:365-73. https://doi. org/10.1007/s12011-015-0422-4.

45. Oettinghaus B, D’Alonzo D, Barbieri E, Restelli LM, Savoia C, Licci M, Tolnay M, Frank S, Scorrano L. DRP1-dependent apoptotic mitochondrial fission occurs independently of BAX, BAK and APAF1 to amplify cell death by BID and oxidative stress. Biochim Biophys Acta. 2016; 1857:1267-76. https://doi.org/10.1016/j.bbabio.2016.03.016.

46. Cipolat S, Martins de Brito O, Dal Zilio B, Scorrano L. OPA1 requires mitofusin 1 to promote mitochondrial fusion. Proc Natl Acad Sci USA. 2004; 101:15927-32. https://doi. org/10.1073/pnas.0407043101.

47. Frezza C, Cipolat S, Martins de Brito O, Micaroni M, Beznoussenko GV, Rudka T, Bartoli D, Polishuck RS, Danial NN, De Strooper B, Scorrano L. OPA1 controls apoptotic cristae remodeling independently from mitochondrial fusion. Cell. 2006; 126:177-89. https://doi. org/10.1016/j.cell.2006.06.025.

48. Arnoult D, Rismanchi N, Grodet A, Roberts RG, Seeburg DP, Estaquier J, Sheng M, Blackstone C. Bax/ Bak-dependent release of DDP/TIMM8a promotes Drp1mediated mitochondrial fission and mitoptosis during programmed cell death. Curr Biol. 2005; 15:2112-18. https://doi.org/10.1016/j.cub.2005.10.041.

49. Lin HY, Lai RH, Lin ST, Lin RC, Wang MJ, Lin CC, Lee HC, Wang FF, Chen JY. Suppressor of cytokine signaling 6 (SOCS6) promotes mitochondrial fission via regulating DRP1 translocation. Cell Death Differ. 2013; 20:139-53. https://doi.org/10.1038/cdd.2012.106.

50. Pyakurel A, Savoia C, Hess D, Scorrano L. Extracellular regulated kinase phosphorylates mitofusin 1 to control mitochondrial morphology and apoptosis. Mol Cell. 2015; 58:244-54. https://doi.org/10.1016/j.molcel.2015.02.021.

51. Eleawa SM, Alkhateeb MA, Alhashem FH, Bin-Jaliah I, Sakr HF, Elrefaey HM, Elkarib AO, Alessa RM, Haidara MA, Shatoor AS, Khalil MA. Resveratrol reverses cadmium chloride-induced testicular damage and subfertility by downregulating p53 and Bax and upregulating gonadotropins and Bcl-2 gene expression. J Reprod Dev. 2014; 60:115-27. https://doi.org/10.1262/jrd.2013-097.

52. Aimola P, Carmignani M, Volpe AR, Di Benedetto A, Claudio L, Waalkes MP, van Bokhoven A, Tokar EJ, Claudio PP. Cadmium induces p53-dependent apoptosis in human prostate epithelial cells. PLoS One. 2012; 7:e33647. https://doi.org/10.1371/journal.pone.0033647.

53. Kumari S, Mehta SL, Li PA. Glutamate induces mitochondrial dynamic imbalance and autophagy activation: preventive effects of selenium. PLoS One. 2012; 7:e39382. https://doi.org/10.1371/journal.pone.0039382.

54. Khatri S, Yepiskoposyan H, Gallo CA, Tandon P, Plas DR. FOXO3a regulates glycolysis via transcriptional control of tumor suppressor TSC1. J Biol Chem. 2010; 285:15960-65. https://doi.org/10.1074/jbc.M110.121871. 
55. Liu L, Gong L, Zhang Y, Li N. Glycolysis in Panc-1 human pancreatic cancer cells is inhibited by everolimus. Exp Ther Med. 2013; 5:338-42. https://doi.org/10.3892/ etm.2012.787.

56. Wang H, Wang L, Zhang Y, Wang J, Deng Y, Lin D. Inhibition of glycolytic enzyme hexokinase II (HK2) suppresses lung tumor growth. Cancer Cell Int. 2016; 16:9. https://doi.org/10.1186/s12935-016-0280-y.

57. Zhai X, Yang Y, Wan J, Zhu R, Wu Y. Inhibition of LDH-A by oxamate induces $\mathrm{G} 2 / \mathrm{M}$ arrest, apoptosis and increases radiosensitivity in nasopharyngeal carcinoma cells. Oncol Rep. 2013; 30:2983-91. https://doi.org/10.3892/ or.2013.2735.
58. Lu J, Ji W, Zhao M, Wang M, Yan W, Chen M, Ren S, Yuan B, Wang B, Chen L. Protamine zinc insulin combined with sodium selenite improves glycometabolism in the diabetic KKAy mice. Sci Rep. 2016; 6:26563. https://doi. org/10.1038/srep26563.

59. Tan S, Chi Q, Liu T, Sun Z, Min Y, Zhang Z, Li S. Alleviation mechanisms of selenium on cadmium-spiked neutrophil injury to chicken. Biol Trace Elem Res. 2017; 178:301-09. https://doi.org/10.1007/s12011-016-0924-8.

60. Pfaffl MW. A new mathematical model for relative quantification in real-time RT-PCR. Nucleic Acids Res. 2001; 29:e45. https://doi.org/10.1093/nar/29.9.e45. 